\title{
The Sino-Russian partnership and global order
}

\section{Bobo Lo ${ }^{1}$}

Received: 24 September 2020 / Accepted: 19 November 2020 / Published online: 8 December 2020 (C) The Institute of International and Strategic Studies (IISS), Peking University 2020

\begin{abstract}
This essay about the Sino-Russian partnership and its relationship to global order makes four main arguments. The first is that the partnership is based on a sober appreciation of the two sides' respective national interests. For all the rhetoric about shared values and common worldviews, this is a pragmatic, interests-based relationship. Second, it is a partnership between strategically autonomous actors, each with its own distinct agenda. Beijing and Moscow agree on much. But they do not operate as a coordinated force in international politics, let alone seek to build a new authoritarian world order. Third, although the rise of China and resurgence of Russia are trends of fundamental importance, the impact of their partnership on global order has been peripheral. Finally, the long-term outlook for the Sino-Russian partnership is uncertain. Against the backdrop of a fluid international environment, Beijing and Moscow face significant challenges in sustaining the momentum of their cooperation.
\end{abstract}

Keywords China $\cdot$ Russia $\cdot$ Global · Order · International · System

\section{Introduction}

The Sino-Russian partnership has become one of the hottest subjects in contemporary international politics. In Beijing and Moscow, the "comprehensive strategic partnership of coordination for a new era" is said to promote "the building of a new international relations based on mutual respect, fairness and justice, and win-win cooperation." Their association is seen not only as mutually beneficial, but also

\footnotetext{
1 Joint statement of the People's Republic of China and the Russian Federation on the development of a comprehensive strategic partnership for collaboration in the new era' June 6, 2019, https://www.bilaterals .org/?joint-statement-of-the-people-s.
}

Bobo Lo

bobolo12chess@gmail.com

1 The Russia/NIS Center, French Institute of International Relations (IFRI), Paris, France 
critical to global order (Fu 2016). ${ }^{2}$ In leading Western capitals, however, a very different narrative prevails. Many policymakers and observers regard China and Russia as posing a direct challenge to Western interests and values, and to the post-Cold War, rule-based international order (White House 2017, 41; Dibb 2019).

Such starkly opposing views have been fuelled by the spiralling crisis in US-China relations, ongoing tensions between Russia and the West, an increasingly unstable global environment, and, most recently, the coronavirus pandemic. Realist theories of international affairs are once again the height of fashion. We appear to be entering a new binarism: on one side, the West and its allies and partners, on the other, the Sino-Russian strategic partnership (Wright 2018), described by some as an "axis of authoritarians" (Ellings et al. 2018) and a "quasi-alliance" (Kashin 2019; Karaganov 2018). ${ }^{3}$ Such is the level of tensions that there is even talk of a "new Cold War" (Wintour 2020).

Such simplifications are all the more seductive at a time of great uncertainty. Yet they are misleading. In this essay, I want to challenge a number of common misconceptions about Sino-Russian partnership and its relationship to global order.

I will make four main arguments. The first is that the Sino-Russian partnership is based on a sober appreciation of the two sides' respective national interests. Despite the rhetoric about shared values and common worldviews, this is above all a pragmatic, interests-based relationship - a prime example of mutualism in action. Beijing and Moscow have few illusions about each other and pursue a coolly rationalist approach to bilateral cooperation. This realism is a strength, lending both clarity and resilience to their engagement.

Second, China and Russia are strategically autonomous actors, with distinct perspectives, agendas, and priorities. They agree on much - above all, the undesirability of a dominant America. But they do not operate as a coordinated force in international politics, much less conspire to build a new authoritarian world order. Theirs is a typical great power relationship. Each side pursues a rigorously interests-based approach to foreign policy. And each is committed to preserving their sovereign freedom of action at almost any cost.

Third, and relatedly, the impact of Sino-Russian partnership on global order has been peripheral to date. Although the rise of China (especially) and resurgence of Russia are individual trends of fundamental importance, strategically their relationship is less than the sum of its parts. The Sino-Russian partnership is less an actor in global affairs than acted upon by external circumstances.

Finally, the fluidity and instability of the international environment-amounting to a new world disorder-point to an uncertain future for the Sino-Russian partnership. Despite its resilience, and the continuing existence of important common interests, Beijing and Moscow face significant challenges in sustaining the momentum of their cooperation.

\footnotetext{
2 In 2016, Fu Ying, the Chair of the Foreign Affairs Committee of the National People's Congress (CPC), argued that Sino-Russian cooperation offered a "model for how major countries can manage their differences and cooperate in ways that strengthen the international system" (Fu 2016, 97).

3 Putin himself has started to refer to the relationship as one between allies: "This is an allied relationship in the full sense of a multifaceted strategic partnership" (Putin 2019).
} 


\section{The rationalism of Sino-Russian relations}

The growth of Sino-Russian cooperation from a 30-year freeze is one of the great success stories of international relations. Considering the bitterness and mistrust between them during the Cold War, the two sides have undergone an extraordinary journey. Today, political ties are as close as they have ever been, further strengthened by the excellent personal rapport between Xi Jinping and Vladimir Putin. ${ }^{4}$ Economically, China is Russia's largest country trading partner, while Russia is China's principal source of energy imports. Their defense, security, cyber, and technological cooperation has expanded impressively in recent years. And they hold similar views on many international issues.

It is worth reflecting on the reasons behind the success of their partnership. The most important driver is a shared recognition that they are far better off having a positive relationship that one which is competitive, let alone confrontational. The Sino-Russian partnership is a prime example of mutualism in a bitterly contested world. As in nature, mutualism describes an association that serves both sides well. It need not be an interaction of equals, or even of equal benefit to both. It does not always imply convergent views of the external world. And it certainly does not mean that Beijing and Moscow agree on everything. What matters is that the relationship is, and is seen to be, mutually beneficial. Self-interest, not emotional attachment, is the key. Indeed, one of the strengths of the Sino-Russian partnership is that it is free from the ideological baggage that undermined the so-called "unbreakable friendship" in the 1950s. Both sides have a clear understanding of what they want, and the confidence to believe that they can achieve their objectives. This gives their partnership real strength and resilience. ${ }^{5}$

\subsection{Mutualism in action}

Sino-Russian mutualism is multifaceted, bringing political, security, geopolitical, and economic dividends. The most immediate of these is a sense of political comfort. Both Zhongnanhai and the Kremlin view foreign policy-and their relationship - as an extension of domestic politics. They aim to facilitate a global environment that supports the legitimacy and stability of their respective regimes. Accordingly, they look to each other for support, assuming the identity of most trusted partner. It helps that they have broadly similar views about the primacy of state sovereignty, the threat posed by "subversive" Western liberal influences, and

\footnotetext{
4 "My friend - and I have every reason to call him a friend - President of the People's Republic of China Xi Jinping and I continuously consult each other on what and how things need to be done ..." See Putin (2020b).

${ }^{5}$ Andrei Kortunov notes that Beijing and Moscow enjoy a smoother and more productive interaction than many allied relationships (Kortunov 2019).
} 
the need for tight central control over politics and society. It is important, too, that public attitudes in both countries are supportive of the relationship. ${ }^{6}$

Such mutualism is especially useful at a time when both governments face mounting criticism of their domestic and foreign policies. China's international reputation is under sustained attack on multiple fronts, with a growing backlash against its military activities in the South China Sea, treatment of the Uighur minority in Xinjiang, influence operations in foreign countries, and "wolf-warrior" diplomacy. Beijing's mishandling of the politics of the coronavirus pandemic, in particular, has fed an anti-China backlash in Europe and Asia as well as the United States (Reuters 2020; Small 2020). ${ }^{7}$ Similarly, Russia's moral standing has been undermined by its military interventions in Ukraine, Syria, and Libya, not to mention episodes such as the poisonings of Sergei Skripal and Alexei Navalny. In these pressured circumstances, mutual solidarity has particular value.

The security benefits of Sino-Russian cooperation arise out of their political empathy. Most importantly, both sides can be confident that neither will attack the other. The territorial question has been settled for the foreseeable future, and it is improbable that China will seek to recover lands lost to Russia as a result of the "unequal treaties" of the nineteenth century. The consolidation of their shared "strategic rear" frees them to focus on other foreign and domestic priorities, rather than worry about each other (Lo 2017, 24-25).

The closeness of Sino-Russian ties also discourages possible attack by third parties. Although there are no mutual defense obligations between Beijing and Moscow-for this is no alliance-Western military planners have at least to consider the possibility that they might come to each other's aid in the event of a major conflict. Unlikely though this scenario may be in reality, it nevertheless gives others pause for thought, and China and Russia potential opportunities for leverage.

The political and security rationale behind the Sino-Russian relationship is buttressed by a larger strategic calculus. Although Beijing and Moscow differ somewhat in their views of international order and Western-led globalization (see below), each views the United States as a clear and present danger to their geopolitical interests-a perception that has been reinforced by the policies of the Trump administration. ${ }^{8}$ In the face of Washington's open hostility, Beijing and Moscow have drawn closer together.

For Moscow, partnership with Beijing also represents a force multiplier for Russian power and influence around the world. Russia carries much more weight internationally in association with China than by itself. Their partnership is the main reason why, for example, US President Donald Trump and French President Emmanuel Macron have reached out to Putin. In acting on the premise that Moscow must be

\footnotetext{
6 A Levada poll from August 2020 ranked China as Russia's closest friend/ally after Belarus. See Levada Center (2020).

7 The biggest change in attitudes has been in Europe, where pro-China sentiments in the wake of the 2008 financial crisis have given way to growing discomfort, resentment and suspicion (Small 2020).

8 The most recent US National Security Strategy identifies China and Russia as the main threats to American interests (White House 2017, 25-28).
} 
prised away from Beijing, these leaders have unwittingly enhanced Russia's global profile and leverage.

Beijing's strategic motivations are somewhat different. It needs good relations with Moscow less as a force multiplier than as a form of insurance. Sino-Russian partnership is central to realizing core Chinese foreign policy goals, such as the Belt and Road Initiative (BRI). In this connection, the 2015 agreement between the Silk Road Economic Belt (SREB) and Putin's Eurasian Economic Union (EAEU) has proved an indispensable confidence-building measure, helping to neutralize Russian fears of strategic displacement by China (Gabuev 2015).

It is a similar story in the Arctic, where the success of Chinese ventures is contingent on Russian permission. There would be no Polar Silk Road unless Beijing had first acknowledged Russia's territorial claims over much of the Arctic Ocean. While Chinese investment and technology have been vital to upstream projects such as Yamal LNG (liquefied natural gas), Russia retains a decisive say on how far Beijing's Arctic goals can be realized.

There is a larger appreciation, too, in Beijing of the influence Russia still wields in the world. For all its supposed decline, it remains a nuclear superpower and China's largest and strongest neighbor. Chinese policymakers have absorbed the lesson of the Western experience with Moscow. However backward or weak Russia has sometimes looked, it retains the capacity to frustrate or negate the objectives of even the most powerful nations, including the United States - and China.

Traditionally, economic ties have been the weakest facet of the Sino-Russian partnership. But even this is changing. With the sharp deterioration of Russia-EU relations in recent years, Moscow has looked toward Beijing to counterbalance the effect of Western sanctions imposed after the annexation of Crimea. As well as being Russia's number one trading partner, China is a critical source of investment for major energy projects, such as Yamal LNG.

As a much larger economy than Russia, China would seem to dominate the economic dimension of the relationship. ${ }^{9}$ But things are more balanced than they appear. Cooperation is based on a complementarity of interests. Chinese manufacturing exports are increasingly penetrating the Russian consumer market, and hi-tech companies such as Huawei are driving a new era of cyber and technological cooperation. Conversely, though, Russia has become China's main source of oil imports, and its sole supplier of high-end military items, such as the S-400 anti-air missile system and Su-35 multipurpose fighter, that are crucial to the modernization of the People's Liberation Army (PLA). And, as already noted, Russian acquiescence is vital to the success of Chinese economic goals in Central Asia and the Arctic.

To sum up, the Sino-Russian relationship may not be one of equals, but this is scarcely the primary consideration - at least for the time being. It matters far more that Beijing and Moscow identify a clear interest in consolidating and expanding their cooperation. Besides, what better alternative does either side have to an engagement that has served them well for nearly three decades? The Sino-Russian

\footnotetext{
${ }^{9}$ China's GDP in 2020 was eight times larger than Russia's—see https://countryeconomy.com/countries/ compare/china/russia.
} 
partnership is not only a success judged on its own terms. It stands out as one of the few relationships that have flourished in a volatile and unpredictable world (RIAC/ Fudan 2020, 10). Mutualism has never seemed more relevant or attractive.

\section{Global order and disorder}

The post-Cold War order is in crisis. Under President Trump the United States has abdicated global leadership, resorting instead to the naked pursuit of national interests under the slogans "America First" and "Make America Great Again" (MAGA). Europe is beginning to fragment along cultural and normative lines, as the liberal consensus unravels in the face of conflicts over identity, the rise of populist nationalism, and the spread of authoritarian values. Transatlantic relations are more damaged than at any time since the Suez crisis of 1956, and the very notion of a unitary "West" has become suspect. The authority of the major Western powers in international institutions has rarely seemed weaker. More broadly, the concept of a "rulesbased international order" has been hollowed out. It is no longer clear what it means or whether it is even worth holding on to.

But despite the crisis of liberalism and the liberal order, a post-Western international system has yet to emerge in its place. China, Russia and India are asserting themselves as global players. However, a multipolar or "polycentric" system remains elusive. The United States may be declining in relative terms-although even this is debatable ${ }^{10}$ _ but it will likely be the leading power in the world over the next two decades, perhaps much longer. Europe will continue to be integral in global affairs, even as it undergoes dislocation and transformation.

Post-Western norms and institutions have struggled to take root. The largely abstract enterprise of the BRICS (Brazil, Russia, India, China, South Africa) is under strain as Brazil under Jair Bolsonaro and India under Narendra Modi steer closer to the United States. The Shanghai Cooperation Organization (SCO) has expanded its membership but achieved little of substance (RIAC/Fudan 2020, 25). Putin's Eurasian Union project has failed to gain traction. Even the relatively successful Asian Infrastructure Investment Bank (AIIB) is just one of several bodies funding development projects in Eurasia, along with the Asian Development Bank (ADB) and World Bank. Perhaps the most successful new multilateral mechanism may turn out to be the Regional Comprehensive Economic Partnership (RCEP), which brings together China, the ten member states of ASEAN, as well as Japan, South Korea, Australia, and New Zealand. But this is still in its very early stages (Financial Times 2020).

\footnotetext{
${ }^{10}$ Over the past decade the United States has actually expanded its share of GDP to 25 percent of the global total, the same percentage as in 1980. Today, more than 90 percent of global financial transactions are dollar-based (Sharma 2020, 71-73).
} 


\subsection{The new world disorder}

There has been a "shift in global power to the East," (Karaganov and Suslov 2020) but the transformation is not from one system to another, but toward a more fluid and fragmented global environment-a new world disorder. This is defined principally by a lack of clarity and agreement over the rules of the international system. It also reflects several other realities.

The most critical is the de-universalization of international norms. We live in an era of moral and cultural relativism, in which the pretence of universal values has been essentially abandoned. Narrow self-interest is the dominant "philosophy" of our time. And what passes for "truth" or morality has become almost entirely subjective, giving way instead to competing national narratives.

Today, there are renascent great power rivalries, notably between Washington and Beijing. Yet paradoxically the limitations of the great powers have rarely been so stark. Under Trump, the United States has become more an anti-model than model of governance - a reality reinforced by its disastrous response to the coronavirus pandemic. China, too, is struggling to persuade others of its leadership credentials or good intentions; anti-Beijing sentiment in many parts of the world-not just the West—is higher than in decades. ${ }^{11}$ Meanwhile, Moscow's ambitions of reasserting its strategic primacy in the post-Soviet space, through schemes such as Greater Eurasia, appear ever more detached from reality.

The relative weakness of the great powers is to some extent inevitable. The world is an infinitely more complex place than during the Cold War. Challenges such as climate change, global poverty and inequality, pandemic disease, the information revolution, and the accelerating pace of technology are beyond the problem-solving capabilities of individual states, however powerful. It is unrealistic to expect a few great nations to run the world, especially when the quality of leadership, in democratic and authoritarian regimes alike, is worse than at any time since the 1930s.

Multilateralism, too, faces an acute crisis of credibility. There have never been so many international organizations, nor a greater need for them, but they have seldom been so ineffective. The UN, IMF, World Bank, and WTO are struggling to remain relevant. Newer bodies, such as the BRICS, the G-20, and the SCO, have been unable to fill the vacuum. Of course, international institutions are only as good as their member states - and leaders. As long as these lack the commitment to develop collective responses to global problems, to look beyond national egoism, there is scant hope that multilateralism can be made to work-as the lamentable reaction to the coronavirus pandemic has highlighted. In this connection, the RCEP hints at a new mindset and hope.

Coronavirus has dramatized the extent of the new world disorder. It has exposed the feebleness of global governance and its institutions; highlighted profound failings of leadership; exacerbated US-China confrontation (RIAC/Fudan 2020, 8);

\footnotetext{
11 Beijing is widely accused in the West of initially suppressing news about the virus, and then using the distraction of the pandemic to expand military operations in the South China Sea and against Taiwan; all this while pursuing a crude international propaganda campaign.
} 
and widened divisions over ideology and identity. In this fraught climate, the stage would appear to be set for the Sino-Russian partnership to play a decisive role in shaping global order. And yet there is no sign of this happening. In the next section, I explain why.

\section{The Sino-Russian partnership in global politics}

On the face of things, Beijing and Moscow hold identical or near-identical views about international affairs (Putin and Xi 2019). They agree on questions of broad principle, such as the need for a multipolar or "polycentric" order no longer dominated by America, the primacy of state-actors, and the vital importance of state sovereignty. Their positions also coincide on a host of more specific issues, including "cyber-sovereignty," Iran, North Korea, opposition to missile defense, and support for a Greater Eurasia. Even in areas that once seemed problematic, such as Central Eurasia and the Arctic, their interaction has proceeded surprisingly smoothly.

\subsection{Same bed, different dreams}

However, in several respects Chinese and Russian views differ substantially. This divergence extends far beyond details of individual policy to encompass fundamental questions of global order and governance. As the prime beneficiary of the postCold War order over the past three decades, China retains a strong vested interest in the maintenance of this order in some form. China's rise from regional backwater to incipient global power might still have occurred under different circumstances, but it has benefited enormously from US global leadership and Western-driven globalization (McGregor 2019, 16).

This order is not perfect, and Beijing has frequently chafed against the constraints of US dominance. Yet overall the balance sheet has been positive. The post-Cold War order has given China unprecedented access to international public goods, natural resources, export markets, and advanced technology. It has provided a permissive environment that has allowed China's leaders to follow their own political course at home. Indirectly, it has reinforced the legitimacy of Communist Party rule by facilitating the country's economic growth and prosperity.

Although Western critics assert that China is a revisionist power, its revisionism is scarcely revolutionary. Beijing seeks to advance Chinese interests by strengthening its position and influence within the existing international system (Yan 2019; Chen Weiss 2019). Accordingly, it has stepped up its activity in various UN bodies, such as the Human Rights Council; developed new multilateral organizations, such as the AIIB; and assiduously promoted an image of China as a good international citizen, for example through Xi's vision of "building a community with a shared future for mankind" (Xinhuanet 2020). Its involvement in Western-led institutionsthe WTO, IMF and World Bank-has also grown substantially. All this reflects an understanding that it is through infiltrating and shaping the international order, 
rather than attempting to replace it, that China can best become "a global leader in terms of composite national strength and international influence” (Xi 2017).

At the same time, Beijing views much of international politics through the prism of the US-China relationship. Although Chinese policymakers repudiate the notion of a G-2, they nevertheless see the interaction between Washington and Beijing as central to twenty-first century global governance (Wang 2019; Huang 2020; Yan 2019). This is perhaps the main reason why the Chinese government strives to maintain a functional relationship with the United States even in the face of rapidly worsening tensions. There can be no global order without some sort of accommodation with Washington, and China requires a benign international environment to flourish and to fulfill long-term aspirations such as the "rejuvenation of the Chinese nation" (China Dream). Conversely, escalating great power tensions, an increasingly fragmented world, rising protectionism and economic decoupling, and military confrontation run directly counter to this vision.

Moscow's thinking is different. The consensus among the Putin elite is that the post-Cold War, US-led order has harmed Russia's development, severely constrained its international prospects, and undermined its national security (Ivanov 2018). They regard the very notion of a "liberal international order" as a self-serving Western construct. $^{12}$ This essential hostility has been systematically reinforced by events over the past 15 years: the 2004 Orange Revolution in Ukraine; the eastward enlargement of NATO; the alliance's 2011 intervention in Libya; and Western sanctions against Moscow in response to the Russian annexation of Crimea and military intervention into the Donbass.

Unlike Beijing, Moscow sees little point in trying to work the post-Cold War order from within. Russia exerts significant influence in the UN Security Council as one of the five permanent members (P5). But otherwise its clout in international institutions is limited. Consequently, the Kremlin has tended to pursue alternative, extra-systemic approaches to asserting Russia's interests.

In the first instance, it prioritizes traditional great power relations, with a particular emphasis on personal engagement between leaders. Putin recently proposed convening a G5 summit of the five permanent members of the UN Security Council to reaffirm "the key principles of behavior in international affairs [and to elaborate] ways to effectively address today's most burning issues" (Putin 2020a). This would in effect circumvent the existing order in favor of a twenty-first century "Concert" of Great Powers that would co-manage the world. Putin's latest proposal follows in the wake of ideas such as a Yalta 2.0, in which global governance would center on a Big Three of the United States, China, and Russia. ${ }^{13}$

The other course Moscow has followed in recent years is that of disruptor, taking advantage of the weaknesses and blank spots in the international system. In Ukraine, Putin reacted against the sudden loss of Russia's dominant influence over Kyiv by ordering unilateral military action. In Syria, he exploited the hesitation of

\footnotetext{
12 "The liberal world order discourse... has never been taken seriously in Moscow" (Lukyanov 2018).

13 Putin has talked up Yalta as the epitome of great power problem-solving, based on "securing and maintaining the existing balance of forces" (Putin 2015).
} 
the Western powers and intervened decisively (and again unilaterally) on behalf of the Assad regime. And in the 2016 US and 2017 French presidential elections, Russia interfered in various ways, safe in the knowledge that it would suffer no significant consequences. Such actions express better than any words the Kremlin's belief that the post-Cold War order is fatally flawed (Financial Times 2019a) and can be bypassed at will.

\subsection{The challenges of strategic cooperation}

The fact that China is a system-player while Russia often seeks to circumvent the system has implications for their strategic cooperation. One partner has a vested interest in functioning international institutions and processes, even while it seeks to turn these to its advantage. The other operates on the basis that a certain amount of disorder or "controllable tension" in the international system is a good thing, not least because it has an equalizing effect among the great powers-sometimes raising Russian influence to the level of China and even the United States.

Such contradictions have not soured the Sino-Russian partnership. Both sides have managed to reconcile their contrasting agendas and priorities, and they are careful to avoid actions that might harm each other's vital (or "core") interests. They recognize, too, that in the current climate they can ill afford to allow their relationship to degrade or stagnate. Nevertheless, the differences between Beijing and Moscow are significant enough to limit their capacity to coordinate policy, let alone allow them to build a post-American world order.

This is apparent from the qualified nature of their engagement in various parts of the world. For example, in the Asia-Pacific Beijing has demonstrated that it is committed to asserting China as the leading power in the region. Moscow's response to such ambition, however, is ambivalent. It is pleased to see China challenging US primacy, yet worries about becoming entangled in a possible military confrontation between Beijing and Washington (Trofimov and Grove 2020). The relationship with China remains the cornerstone of Russian policy in Asia, but Putin has also stepped up efforts to diversify relations with other Asian powers, such as India, Japan and Vietnam, as well as with pan-Asian institutions. Moscow follows Beijing's lead on North Korea, but only because it has no independent influence on the peninsula.

More generally, Putin is committed to positioning Russia as an independent center of regional and global power. This means preserving strategic flexibility and not becoming hostage to Chinese goals. ${ }^{14}$ For although Moscow values the SinoRussian partnership as a force multiplier, it frets about becoming overly dependent on Beijing. So, in addition to diversifying ties across Asia, it also aims to maintain close economic links with Europe and some level of stable interaction with the United States; to reinforce Russian political and security influence in the post-Soviet space; and to avoid excessive commitments in its bilateral relationship with China.

\footnotetext{
${ }^{14}$ As Dmitri Trenin observes, "[t]he key and absolutely indispensable element of Russia's status has been independence." He notes, further, that "[n]ational independence implies a sovereign foreign policy" and that "Russia seeks a status that is equal to that of any other major world power" (Trenin 2019a).
} 
None of this is to suggest that Moscow is looking to move away from Beijing. Rather, the ambition is to have it all—strategic partnership with China, diversified relations in Asia, revived cooperation with Europe, functional interaction with the United States, and a place for Russia at the heart of whatever international system or order eventually emerges. To achieve any, let alone all, of these objectives, Moscow cannot afford to be seen by others as Beijing's "loyal helper". 15

Beijing is no less wary of Russian aims. While it deplores grassroot democratic movements such as the Maidan revolution that overthrew President Viktor Yanukovych in Ukraine in 2014, it has no interest in helping Putin to re-assert a dominant Russian influence over the post-Soviet space. It has pursued its own agenda with the Europeans, taking care to distance itself from the crisis in Russia-EU relations. In the Middle East, China has important economic interests, but is a negligible geopolitical presence and therefore minds its own business. Grand ventures such as the BRI require Russian acquiescence (see above), but Moscow's direct involvement is hardly necessary and can sometimes be counterproductive.

Moreover, Moscow's support on international issues is not always an unequivocal blessing. It is useful in some issue-areas, such as countering Western criticisms of China's human rights record or PLA actions in the South China Sea. But Russia's system-disrupting behavior is sometimes at odds with China's more measured and methodical approach to exploiting the advantages of the international system. Association with a state that annexes the territory of a sovereign neighbor (Ukraine) and encourages the use of chemical weapons (in Syria) incurs certain reputational costs for Beijing.

\subsection{Less than meets the eye}

Despite charges of Sino-Russian collusion, the evidence points to the oppositeBeijing and Moscow pursue separate agendas with little or no reference to each other. Their summit communiques are full of sentiments about solidarity, and they coordinate their voting in the UN Security Council, most notably in vetoing Western-sponsored resolutions on Syria. But beyond those formal institutional confines, joint Sino-Russian action in the international arena is limited. Moscow's military interventions in Ukraine in 2014, and Syria in 2015, took place with no prior consultation with the Chinese leadership. Equally, Beijing does not seek Moscow's blessing when it pursues its own interests in the South China Sea, clamps down on Hong Kong, or ratchets up the pressure against Taiwan.

In all these instances, the Sino-Russian partnership provided a reassuring backdrop, but was hardly a game-changer. Foreign policy decisions remain a wholly sovereign affair. The partner's approval is largely superfluous, while potential disagreements are managed by maintaining a public neutrality or discreet silence. ${ }^{16}$ Beijing and Moscow stay clear of each other's most controversial issues. Thus, China

\footnotetext{
15 "In the long run, Russia needs to balance its relationship with its giant and fast-growing neighbor, so as to protect its own sovereignty and avoid becoming a mere sidekick" (Trenin 2019b).

16 As Trenin remarks, the Sino-Russian relationship is guided by the principle of "never against each other, not always with each other" (Trenin 2020).
} 
has adhered to a neutral position on Ukraine, while becoming that country's largest external investor after the EU. And although Russia has criticized US freedom-ofnavigation operations in the South China Sea, it has avoided taking sides on questions of territoriality.

Even in areas where Chinese and Russian interests appear to converge, there is little synchronization. In Eurasia, their partnership functions on the basis of a rough division of labor: Russian political and security leadership alongside China's economic domination. The priority here is accommodation rather than active cooperation. In this connection, the construct of a Greater Eurasia offers something to both sides. For Moscow, it is a means of formalizing and preserving Russia's leading position in Eurasia, and of ensuring an acceptable balance of influence with China. For Beijing, paying lip-service to such an abstraction is helpful in allaying Russian strategic anxieties, and removing roadblocks to the development of the BRI. In other words, Sino-Russian partnership in Eurasia operates mainly in a trouble-shooting mode-reconciling different and potentially contradictory priorities.

There has been much speculation about the expansion of Sino-Russian military ties, to the point that some observers see this as signaling an alliance in all but name (Kashin 2019; Karaganov 2020). The reality is less dramatic. Although the PLA has participated in several large Russian-led and bilateral military exercises, interoperability between the two armed forces is minimal (Gorenburg 2020). Similarly, while Russian transfers of military equipment to China have increased substantially in recent years, Moscow still sells more hi-tech weaponry to India and has greatly expanded exports to other Asian countries, such as Vietnam, Indonesia, and Turkey. Its motivations are straightforward: to exploit one of Russia's few comparative economic advantages, and to raise its profile and influence in Asia. If defense cooperation with China spooks Western foreign and defense policy establishments into paying greater attention to Russia, then so much the better. But that is not the Kremlin's primary intention.

\subsection{The fallacy of the strategic triangle}

It has become fashionable in the West to entertain the idea of weakening the SinoRussian partnership by seeking an accommodation with Moscow. This is essentially a "reverse-Nixon." Whereas the former US president opened up a second front in the Cold War against the Soviet Union by reaching out to Mao Zedong, today the hope is that a rapprochement with Russia will help contain China.

This thinking, however, is flawed on several counts. First, it underestimates the value of the Sino-Russian partnership to Moscow-and to Putin personally. Its expansion is perhaps the greatest foreign policy achievement of his 20 -year presidency, aside resurrecting Russia as a serious international player. As noted earlier, the relationship has served Russian interests very well across multiple domains. And there is every reason to suggest this will remain the case. 
Second, Russia can ill afford a deterioration in relations with China. Such a turn of events would have an adverse impact on Russia's national security, its ability to project power and influence, and economic prospects. The presence of a hostile or even indifferent China would weaken Moscow's leverage vis-à-vis the West and call into question its viability as an independent global actor. Unlike the Soviet Union, which was able to sustain a two-front strategic confrontation with the United States and China, contemporary Russia has no such capability. It would face the very real threat of marginalization, if not worse.

Third, the West has little to offer Putin - and would not be believed in any case, given the deep mistrust between them. Recent overtures by Washington and Paris have been big on rhetoric but offered nothing concrete. In June 2020 Trump called for Putin to be invited to the next G7/G11 summit in 2021 (Borger 2020), but this proposal was quickly rejected by other G-7 leaders. Meanwhile, the administration's Russia policy has actually been tougher than under Barack Obama. ${ }^{17}$ Similarly, Macron talks vaguely of bringing Russia in from the cold, ${ }^{18}$ but is opposed by other EU leaders (Financial Times 2019b). The bottom line, instinctively understood by all sides, is that the West cannot deliver what Putin wants, namely, full recognition of Russia's geopolitical and normative equality with the West. This would entail, among other things, de facto recognition of Moscow's annexation of Crimea, the lifting of Western sanctions, and political and economic support for the Russian position in Syria - all highly improbable.

The only viable course for Moscow is the one Putin is already pursuing: to keep all sides interested and maximize Russia's options. In practice, that means leaning toward Beijing, but not tying itself too closely to Chinese objectives. It means encouraging Western partners to believe in the possibility of improved relations with Moscow, while also playing on their insecurities. Most of all, it means promoting Russia as a sovereign actor, ready and able to do business with all, but beholden to none.

\section{The future of Sino-Russian partnership in a changing world}

There is no doubt that the rise of China and the resurgence of Russia are trends of global significance. But it is important to distinguish between their individual impact, and that of the Sino-Russian partnership itself. Although bilateral cooperation has blossomed, and the two sides appear likeminded in many respects, there is

\footnotetext{
17 US sanctions against Moscow have expanded under CAATSA (Countering America's Adversaries Through Sanctions Act) while Washington has withdrawn from the INF Treaty. Trump's Secretary of State Mike Pompeo has also been at the vanguard of efforts to kill off the Nordstream-2 gas pipeline project.

18 Foreshadowing a world centering on "two main focal points: the United States and China," Macron has argued that "pushing Russia away from Europe [would be] a major strategic error, because we are either pushing it toward isolation, which heightens tensions, or toward other great powers such as China, which would not at all be in our interests" (Macron 2019).
} 
little active coordination between Chinese and Russian foreign policy. Beijing and Moscow are careful not to step on each other's toes, but they function autonomously.

As a result, the Sino-Russian partnership has had only a modest impact on international politics. The closeness of their ties worries Western leaders, leading some of them to reach out to Putin. But most of the West's anxieties relate to specific Chinese (and, to a much lesser extent, Russian) policies: the PLA's growing assertiveness in the South China Sea and over Taiwan; Beijing's United Front work overseas; cyber activity against Western targets; the mass incarceration of Uighurs and the security clampdown on Hong Kong; and forced technology transfers from foreign companies operating in China. Russia's involvement in these areas is minimal to non-existent. ${ }^{19}$ In general, Western governments are far more allergic to what they see as China's untrammeled strategic ambition and expanding capabilities than they are to the Sino-Russian partnership.

Looking ahead, the question is whether the Sino-Russian partnership can develop into a more cohesive and influential force in international politics, or whether the current modus operandi between Beijing and Moscow-bilateral cooperation alongside separate foreign policies-will continue indefinitely. There are several possible scenarios, but the common denominator is that it will be the international situation-global order/disorder - that will shape the Sino-Russian partnership, rather than the other way around.

\subsection{The accommodation scenario}

One scenario is premised on a sea change between Washington and Beijing. Although US-China relations would remain complicated, both sides would be more disposed to work together, not just on bilateral issues, but also on larger challenges such as climate change and security in the Asia-Pacific.

Although this scenario appears improbable, it should not be ruled out altogether. The increasing gravity and urgency of universal threats such as climate change, pandemic disease, and global poverty could conceivably lead to just such an outcome. Admittedly, this has not happened in the case of the coronavirus pandemic, which has aggravated existing animosities. But with the feel-good factor of a Biden presidency, a greater sense of urgency about climate change, and recognition that unalloyed great power rivalry could end disastrously, who knows what might be possible? It is worth recalling at this point that the Cold War ended only a few years after a particularly antagonistic era of US-Soviet rivalry in the early 1980s. Today's "truths" can quickly become tomorrow's anachronisms under the impact of events (or Black Swans). ${ }^{20}$

\footnotetext{
${ }^{19}$ Conversely, Beijing had nothing to do with Moscow's de facto occupation of parts of Ukraine, its aggravation of the conflicts in Syria and Libya, interference in the 2016 US presidential and 2017 French presidential elections, or the attempted assassinations of Sergei Skripal and Alexei Navalny.

${ }^{20}$ Nassim Taleb, the originator of the concept of a Black Swan, defines it as an outlier event that has huge impact, but which was predictable in retrospect (Taleb 2010, xxi).
} 
If a US-China accommodation became a reality, there could be serious consequences for Sino-Russian partnership-unless, of course, there were a parallel rapprochement between Moscow and Washington (and leading European capitals). Focused on their own growing engagement, China and the United States might become less inclined (or careful) to take Russian interests and sensibilities into account. The resulting sense of insecurity in Moscow could lead it to engage in attention-seeking behavior, to remind others that Russia still counts. One thing is certain: the Kremlin would not meekly accept Russia's demotion to the status of a second- or even third-tier power. It would demand "respect" from Beijing as well as Washington, and Chinese policymakers would need to tread cautiously.

\subsection{The (relative) stability scenario}

This scenario is predicated on a measure of stability in the international system. Although some global trends might become more negative, there would be few shocks or radical shifts in direction. Geopolitical rivalries would remain uppermost in the minds of the major powers but would be unlikely to escalate into direct confrontation. Problem-solving would be elusive, and multilateral institutions-and cooperation-weak. But international society would avoid the worst.

Even with a Biden administration in Washington, the US-China relationship will still be deeply problematic, with ongoing disputes over freedom of navigation, South China Sea territoriality, Taiwan, cyber and political interference, 5G technology, trade and intellectual property, and the human rights situation in Xinjiang and Hong Kong. Regardless of how China evolves, it will invariably be regarded as the threat to US global primacy (Wang 2019). At the same time, Washington and Beijing may manage to cooperate in some areas, such as combating climate change. Generally speaking, American policy would be more predictable, and this might lead to a certain stabilization, although not necessarily improvement, in US-China interaction.

US-Russia relations would continue to be difficult, and Moscow might come under greater pressure as some degree of Transatlantic consensus is restored. There would be no relief on sanctions or special deal-making over Ukraine or Syria. That said, Russia might welcome the return to a partial normality in relations with the West. Although it has benefited from the damage Trump has inflicted on the Western alliance, a Biden presidency could turn out to be safer in the long run (Stanovaya 2020). There would be an extension to the START agreement, and the Kremlin could rest easy in the knowledge that a US-China strategic rapprochement would remain a distant prospect.

Under this scenario, the Sino-Russian partnership would not be subjected to any real stress tests, and might even expand further. However, there would be no quantum leap to a new type of relationship. Both sides would pursue autonomous foreign policies, and the influence of their partnership in international affairs would be circumscribed. In the longer term, the widening economic and technological gap between China and Russia could lead to some tensions, especially if Beijing became more assertive as a result. Equally, though, both sides might be able to adjust to this evolving reality. 


\subsection{The confrontation scenario}

To many observers, the most probable scenario is for growing US-China rivalry leading to eventual conflict, almost certainly in the western Pacific, but possibly elsewhere as well. Obvious trigger points include clashes over US freedom-ofnavigation operations; an attempt by Beijing to forcibly reunify Taiwan with the mainland; and disputes over the future of the Korean peninsula. US-China tensions could rise to critical levels. A localized conflict might become a matter of "when" rather than "if." It would also be harder to resolve peacefully, unlike, say, the EP-3 plane incident near Hainan in 2001. Then, both the bilateral context and the international situation were much more stable. China was also considerably weaker, both in absolute terms and relative to the United States.

If a US-China confrontation ensues, the Sino-Russian partnership could face its greatest challenge since the 1980s. Washington and Beijing would exert strenuous efforts to court Moscow. While this might seem to strengthen Russia's hand, in reality matters would not be so simple.

The Kremlin is already anxious about becoming embroiled in spiralling tensions between Washington and Beijing (Trenin 2020). If this rivalry should escalate to the point of conflict, Moscow could face some very uncomfortable choices. If it steps up support for Beijing, including by offering material and not just moral assistance, it risks a further serious downturn in relations with the United States, as well as with US allies and partners in Europe (Germany, France) and Asia (Japan, India). But if it adopts a more hands-off approach, it could damage the Sino-Russian partnership without obtaining any compensating gains vis-à-vis the West.

The likelihood is that the Kremlin would cling to the Sino-Russian partnership, which is much more tangible than anything the West can offer. But the real issue is how far Moscow would back Beijing in a confrontation with Washington. The answer is probably not far at all. We could expect declarations of political support, some criticism of US actions and policies (as today), calls for restraint by both sides, and offers to broker a diplomatic solution. Contrary to the fears of some Western defense planners, the Russian military would stay clear of direct involvement in a US-China conflict. Moscow would also be careful to avoid any suggestion that it was running interference on behalf of Beijing by opening up a second front in Europe or the Middle East. As always, the Kremlin's actions would be guided by its calculation of Russian national interests rather than loyalty to a strategic partner. ${ }^{21}$

In the confrontation scenario, the Sino-Russian partnership might survive, but not undamaged. It would be unlikely to function as a cohesive force. Beijing might wish to upgrade the relationship into a bona fide political-military alliance. But in such a volatile context Moscow would almost certainly opt to preserve strategic flexibility. Indeed, it may view such circumstances as offering a golden opportunity to position Russia as the global "swing power", balancing between China and the United States (Karaganov 2020).

\footnotetext{
${ }^{21}$ A notable example of this was Putin's decision to support the US intervention in Afghanistan in 2002 without consulting or even informing Beijing beforehand.
} 


\section{Reinventing Sino-Russian partnership for a new era?}

The long-term future of Sino-Russian partnership may depend on the capacity to reinvent and repackage itself. As a traditional great power relationship, focused on geopolitical and security priorities, its prospects are limited. One of its principal weaknesses is that many countries-in the non-West as well as the West-view it primarily as a negative or defensive partnership against the United States, and not as a positive ("win-win") model of engagement. While this picture may be misleading, Moscow and Beijing are to some extent responsible for it. There has been too much loose talk about a multipolar world, and some of the anti-American and anti-Western rhetoric has been wildly intemperate. ${ }^{22}$ This has been aggravated by the reputational damage arising from their respective domestic and foreign policies. Fairly or unfairly, China and Russia are seen as aggressor states, not only in the West, but also by many of their neighbors.

Beijing and Moscow, then, face formidable difficulties in persuading others of their good intentions. Yet there is room for the Sino-Russian partnership to move in this direction. One way is to take the lead on some of the issues that have been badly neglected by the US-led post-Cold War order, such as climate change and global poverty. Contrary to the realist narrative, these are the true existential challenges of our time. Just as in history nations have often been guilty of "fighting the last war," so there is a danger of obsessing about traditional geopolitical constructs instead of addressing the clear and present dangers of the twenty-first century.

It is also no longer sufficient to intone noble sentiments about global governance, the "democratization" of international relations, and the "spirit of multilateralism." Beijing and Moscow will have to act on these if they are serious about developing a new quality of partnership, one that might become a model for others to follow. In the process, they will need to adapt to a world that is evolving in extraordinary and unpredictable directions. That will require thinking beyond conventional—and self-centered-understandings of national interests and embracing a more generous vision of the global good.

\section{Compliance with ethical standards}

Conflict of interest The author declares that there is no competing interests.

\section{References}

Borger, Julian. 2020. Donald Trump offers to invite Vladimir Putin to expanded G7 summit. The Guardian. https://www.theguardian.com/world/2020/jun/01/donald-trump-vladimir-putin-g7-call. Accessed 1 June 2020.

Chen Weiss, Jessica. 2019. A world safe for autocracy? Foreign Affairs 98 (4): 93.

\footnotetext{
22 As the RIAC/Fudan annual report emphasizes, "anti-Americanism cannot become the basis of the Russia-China partnership" (RIAC-Fudan 2020, 85).
} 
Dibb, Paul. 2019. How the geopolitical partnership between China and Russia threatens the West. Australian Strategic Policy Institute Special Report. https://www.aspi.org.au/report/how-geopoliticalpartnership-between-china-and-russia-threatens-west. Accessed November 2019.

Ellings, Richard, and Robert Sutter (eds). 2018. Axis of authoritarians: implications of China-Russia cooperation, National Bureau of Asian Research. https://www.nbr.org/event/axis-of-authoritariansimplications-of-china-russia-cooperation/. Accessed October 2018.

Financial Times. 2019a. Vladimir Putin says liberalism has "become obsolete". https://www.ft.com/conte nt/670039ec-98f3-11e9-9573-ee5cbb98ed36. Accessed 28 June 2019.

Financial Times. 2019b. Emmanuel Macron's pivot to Russia sparks EU unease. https://www.ft.com/ content/00ac54f4-d30f-11e9-8367-807ebd53ab77. Accessed 11 September 2019.

Financial Times. 2020. Asia-Pacific countries sign one of the largest free trade deals in history. https:// www.ft.com/content/2dff91bd-ceeb-4567-9f9f-c50b7876adce. Accessed 15 November 2020.

Fu, Ying. 2016. How China sees Russia. Foreign Affairs 95 (1): 97.

Gorenburg, Dmitry. 2020. An emerging strategic partnership: trends in Russia-China military cooperation. Security Insights 54: 5-7.

Huang, Yukon. 2020. China is hostage to a rules-based multilateral system. Carnegie Endowment for International Peace. https://carnegieendowment.org/2020/09/10/china-is-hostage-to-rules-based -multilateral-system-pub-82679. Accessed 10 September 2020.

Ivanov, Igor. 2018. Russia's post-election foreign policy: new challenges, new horizons. Russia in Global Affairs. http://eng.globalaffairs.ru/book/Russias-Post-Election-Foreign-Policy-New-Challenges -New-Horizons-19458. Accessed 28 March 2018.

Karaganov, Sergei. 2018. China and Russia are quasi allies .... The Times of India. https://timesofind ia.indiatimes.com/blogs/Globespotting/china-and-russia-are-quasi-allies-on-strategic-affairs-russi a-and-india-have-serious-conversations-only-at-top-level/. Accessed 28 February 2018.

Karaganov, Sergei. 2020. The future of the big triangle. Russia in Global Affairs. https://eng.globalaffairs. ru/articles/future-big-triangle/. Accessed 29 June 2020.

Karaganov, Sergei, and Suslov Dmitry. 2018. A new world order: a view from Russia. Russia in Global Affairs. $\quad$ https://eng.globalaffairs.ru/pubcol/A-new-world-order-A-view-from-Russia--19782. Accessed 4 October 2018.

Kashin, Vasily. 2019. Tacit alliance: Russia and China take military partnership to new level. Carnegie Moscow Center. https://carnegie.ru/commentary/80136. Accessed 22 October 2019.

Kortunov, Andrei. 2019. Who will build the new world order? Russian International Affairs Council. https://russiancouncil.ru/en/analytics-and-comments/analytics/who-will-build-the-new-world-order 1. Accessed 6 June 2019.

Levada Center. 2020. Attitudes toward countries. https://www.levada.ru/en/2020/09/30/attitudes-towar d-countries. Accessed 30 Sept 2020

Lo, Bobo. 2017. A wary embrace: what the China-Russia relationship means for the world. A Lowy Institute Paper. Penguin Random House Australia.

Lukyanov, Fyodor. 2018. Trump's defense strategy is perfect for Russia. Russia in Global Affairs. http:// eng.globalaffairs.ru/redcol/Trumps-defense-strategy-is-perfect-for-Russia-19312. Accessed 24 January 2018.

Macron, Emmanuel. 2019. Speech to French Ambassadors. https://lv.ambafrance.org/Ambassadors-confe rence-Speech-by-M-Emmanuel-Macron-President-of-the-Republic. Accessed 27 August 2019.

McGregor, Richard. 2019. Xi Jinping: the backlash. A Lowy Institute Paper. Penguin Random House Australia.

Putin, Vladimir. 2019. Speech to the Valdai Club. http://en.kremlin.ru/events/president/news/61719. Accessed 3 October 2019.

Putin, Vladimir. 2020a. Virtual address at the 75th session of the UN General Assembly. http://en.kreml in.ru/events/president/news/64074. Accessed 22 September 2020.

Putin, Vladimir. 2020b. Remarks to the Valdai Club. http://en.kremlin.ru/events/president/news/64261. Accessed 22 October 2020.

Putin, Vladimir, and Jinping Xi. 2019. Summit press statements. http://en.kremlin.ru/events/president/ news/60672. Accessed 5 June 2019.

Reuters. 2020. Internal Chinese report warns Beijing faces Tiananmen-like global backlash over virus. https://www.reuters.com/article/us-health-coronavirus-china-sentiment-ex/exclusive-internal-chine se-report-warns-beijing-faces-tiananmen-like-global-backlash-over-virus-idUSKBN22G19C. Accessed 4 May 2020. 
RIAC/Fudan. 2020. Russia-China Dialogue: The 2020 Model. Joint report of the Russian International Affairs Council, Fudan University, and the Institute of Far Eastern Studies of the Russian Academy of Sciences. https://russiancouncil.ru/en/activity/publications/russia-china-dialogue-the-2020-model /. Accessed 27 August 2020.

Sharma, Ruchir. 2020. The comeback nation: U.S. economic supremacy has repeatedly proved declinists wrong. Foreign Affairs 99 (3): 71-73.

Small, Andrew. 2020. The meaning of systemic rivalry: Europe and China beyond the pandemic. European Council on Foreign Relations policy brief. https://www.ecfr.eu/publications/summary/the_ meaning_of_systemic_rivalry_europe_and_china_beyond_the_pandemic. Accessed 13 May 2020.

Stanovaya, Tatyana. 2020. A farewell to Trump? Russia's elite braces for US elections. Carnegie Moscow Center. https://carnegie.ru/commentary/83007. Accessed 21 October 2020.

Taleb, Nassim. 2010. The Black Swan: the impact of the highly improbable. Revised edition. Penguin Random House UK.

Trenin, Dmitri. 2019a. Russia's changing identity: in search of a role in the $21^{\text {st }}$ century. Carnegie Moscow Center. https://carnegie.ru/commentary/79521. Accessed 18 July 2019.

Trenin, Dmitri. 2019b. How cozy is Russia and China's military relationship? Carnegie Moscow Center. https://carnegie.ru/2019/11/19/how-cozy-is-russia-and-china-s-military-relationship-pub-80363. Accessed 19 November 2019.

Trenin, Dmitri. 2020. How can Russia maintain equilibrium in the post-pandemic world? Carnegie Moscow Center. https://carnegie.ru/commentary/81702. Accessed 1 May 2020.

Trofimov, Yaroslav, and Thomas Grove. 2020. Weary Russia tries to avoid entanglement in US-China spat. Wall Street Journal. https://www.wsj.com/articles/weary-russia-tries-to-avoid-entanglementin-u-s-china-spat-11592654401. Accessed 20 June 2020.

Wang, Jisi. 2019. Assessing the radical transformation of US policy toward China. China International Strategy Review 1 (2): 202-203.

White House. 2017. National Security Strategy of the United States of America. https://www.whitehouse .gov/wp-content/uploads/2017/12/NSS-Final-12-18-2017-0905.pdf.

Wintour, Patrick. 2020. US vs China: is this the start of a new cold war? The Guardian. https://www. theguardian.com/world/2020/jun/22/us-v-china-is-this-the-start-of-a-new-cold-war. Accessed 22 June 2020.

Wright, Thomas. 2018. The return to great-power rivalry was inevitable. The Atlantic. https://www.brook ings.edu/opinions/the-return-to-great-power-rivalry-was-inevitable/. Accessed 12 September 2018.

Xi, Jinping. 2017. Report to the 19th Party Congress. Xinhuanet. http://www.xinhuanet.com/english/ special/2017-11/03/c_136725942.htm. Accessed 18 October 2017.

Xinhuanet. 2020. Xi says COVID-19 fight adds urgency to building community with shared future for mankind. http://www.xinhuanet.com/english/2020-03/25/c_138913228.htm. Accessed 25 March 2020.

Yan, Xuetong. 2019. The age of uneasy peace. Foreign Affairs 98 (1): 40. 